\title{
HISTOPATHOLOGICAL AND HISTOMORPHOMETRIC STUDIES ON THE EFFECTS OF OLANZAPINE ON KIDNEY: AN EXPERIMENTAL STUDY IN ALBINO RATS
}

\author{
Waqar Akram, Nafis Ahmad Faruqi \\ Department of Anatomy, Jawaharlal Nehru Medical College and Hospital, AMU, Aligarh, UP, India
}

\begin{abstract}
Introduction: Olanzapine, a widely used atypical antipsychotic agent is known to cause nephrotoxic effects after prolonged use. Aim of the study was to find out detailed histopathological and histomorphometric information which might throw light on the mechanism of toxicity of olanzapine.
\end{abstract}

Material \& Methods: Twelve albino rats were divided into equal number of experimental and control groups i.e. 6 each. Experimental rats received olanzapine, $4 \mathrm{mg} / \mathrm{kg}$, intraperitoneally for 6 weeks. Kidney tissue was processed for $\mathrm{H} / \mathrm{E}$ stain.

Observation \& Results: Extensive degenerative changes with generalized edema was observed as histopathological findings. Histomorphometry showed shrinkage of Bowman's capsule and glomeruli.

Conclusion: Degeneration of kidney due to prolonged use of olanzapine is confirmed which might be due to direct effect on the organ or indirect effect due to toxicities on other organs.

Keywords: Olanzapine, kidney, albino rats.

\section{INTRODUCTION}

Olanzapine is a widely used atypical antipsychotic agent, approved by the U.S. Food and Drug Administration for bipolar disorder and schizophrenia [1]. Olanzapine is a newer atypical antipsychotic agent with a pharmacological profile very similar to that of clozapine [2]. In human brain tissue, olanzapine exhibits very high affinity for the $\mathrm{H} 1$ histamine receptors and 5-HT 2A and 5-HT 2C receptors [3]. It also shows affinity for D2 receptors, muscarinic and alpha 1 receptors with lower affinity for alpha 2, 5- HT 1D and 5-HT1A receptors [3]. Such affinity pose danger to wide range of organs in the body.

Urogenital system has attracted special attention from most of the scientists because of its direct impact on fertility. Nephrotoxic effects of chronically administered olanzapine in male rats was reported by Gulec et. al. (2012) [4]. Acute kidney injury (AKI; a rapid decline in kidney function) has been attributed to atypical antipsychotic drugs in several case reports $[5,6]$. Marked elevations of serum CK [7-10] and urinary incontinence [11,12] as side effects of olanzapine have been well reported. Despite of extensive exploration on nephrotoxic effects of olanzapine, scientists couldn't fully ascertain the mechanism of action and suggested further investigations. Detailed histopathological and histomorphometric studies of effects of olanzapine on kidney are lacking in literature. Such informations are directly related to the affinity of drug to these organs which might throw light in finding the mechanism of action.

\section{MATERIAL AND METHODS}

Twelve male albino rats (Rattus Norwegicus) weighing around $180-200 \mathrm{gm}$ were divided into equal number of experimental and control groups i.e. 6 each. Rats have ready access to water ad-libitum and standard pellet laboratory diet (Lipton India Limited). Olanzapine (inj. Oleanz, Sun Pharmaceuticals, Mumbai, India) was 
Effects of olanzapine on the kidney of albino rats......

injected daily intraperitoneally in experimental rats at a dose of $4 \mathrm{mg} / \mathrm{kg}$ for 6 weeks. Control group received same volume of normal saline, daily, intraperitoneally for the same period. After proposed experimental duration of 6 weeks exposure, the animals of both the experimental and control groups were anaesthetized by giving injection Nembutol (30 mg/kg), intraperitoneally. The heart was exposed by thoracotomy. The needle of the blood transfusion set was introduced into the left ventricle (apex) and a nick was made in the right atrium. After saline wash, Karnovsky's fixative was infused till the body showed signs of fixation.

A midline abdominal incision was made to identify and dissect the kidney (Fig. 1). Tissue was processed by wax embedding technique. $10 \mu \mathrm{m}$ thick sections of both experimental and control kidneys were stained with haematoxylin and eosin.

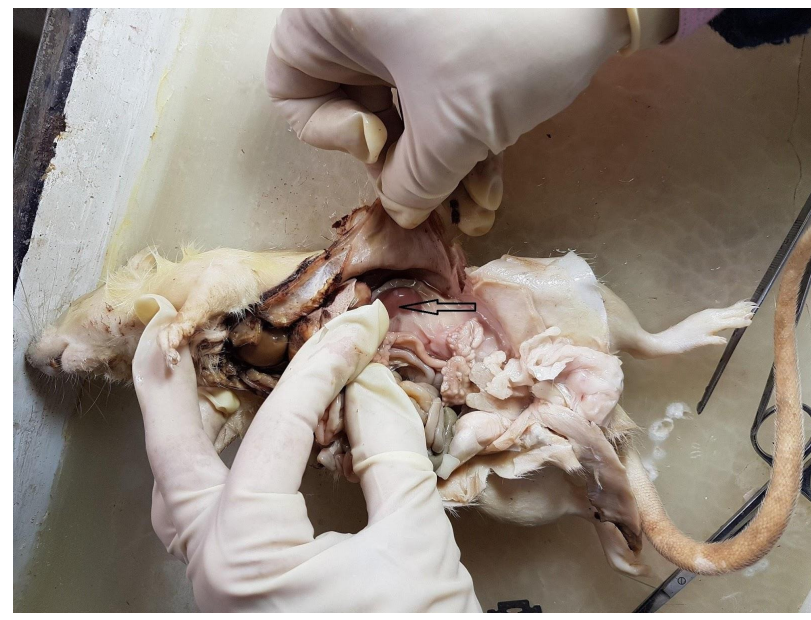

Fig. 1: Photograph of dissection showing exposed left kidney (arrow) of male albino rat

After thorough histopathological observations, histomorphometry was done in glomerulus, Bowman's capsule, proximal and distal convoluted tubules to find out any enlargement or shrinkage. Diameters measured were always external and in two directions to get mean values for the purpose of accuracy.

\section{OBSERVATIONS AND RESULTS}

\section{Histopathology}

Photomicrograph of control kidney cortex showed Bowman's capsule, glomeruli made up of bunch of patent capillaries and nuclei (around 30 in number) representing epithelial, endothelial and mesenchymal cells. Urinary spaces were clear. Tubules were lined by single layer of cuboidal cells with clear lumina. Visceral epithelium, mesangial and endothelial cells were seen in capillary tuft. Flat cells of parietal epithelium line the outer border of urinary space. A small distal convoluted tubule with prominent nuclei close together is part of juxtaglomerular apparatus were seen adjacent to glomerulus (Fig. 2).

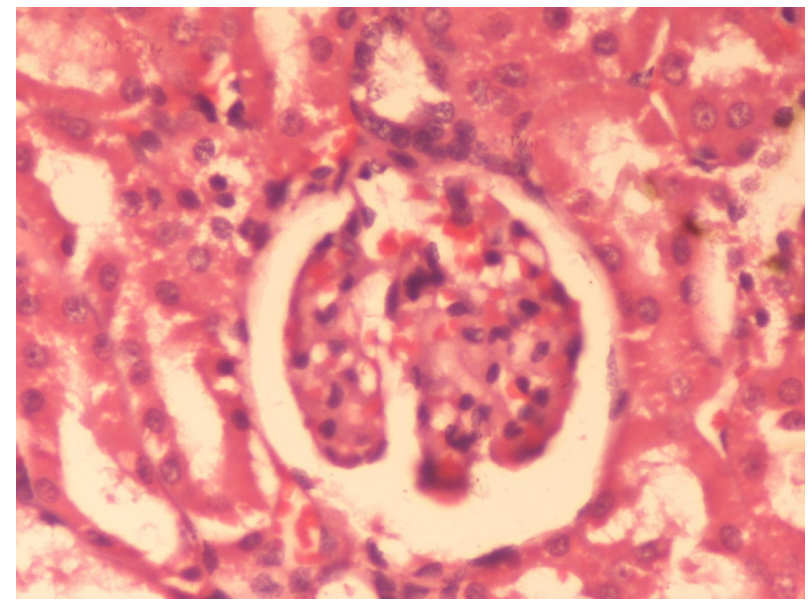

Fig. 2: Photomicrograph of control kidney: Glomerulus showing Bowman's capsule and afferent arteriole entering the capillary tuft. Visceral epithelium, mesangial and endothelial cells seen in capillary tuft. Flat cells of parietal epithelium line the outer border of urinary space. A small DCT with prominent nuclei close together is part of JGA seen adjacent to glomerulus. Tubules lined by cuboidal epithelium showing round nuclei and eosinophilic cytoplasm. Urinary space and tubule lumina are clear (H\&E, 40X)

Experimental kidney glomeruli showed edema and swollen capillary tuft, increased number of nuclei, hemorrhage, acute inflammatory cells and dilated capillaries. Tubules also showed edema and wide open lumina. Around 50 nuclei were seen in glomeruli. Albumin, fibrin and blood cells were seen in urinary spaces and tubules. Arterioles were dilated. There was proliferation of mesangial cells and swelling of both parietal and visceral epithelial cells of Bowman's capsule. Denudation of parietal epithelium cells from basement membrane was also seen (Fig. 3). The proximal convoluted tubules were lined by degenerating cuboidal cells with highly eosinophilic cytoplasm and wisps of cytoplasm projecting in lumina (Fig. 4). 


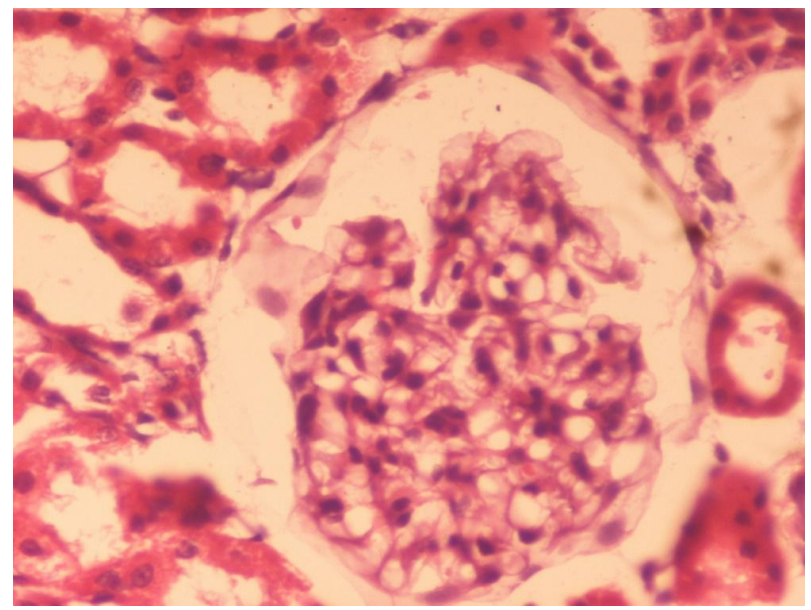

Fig. 3: Photomicrograph of experimental kidney: Section showing features of acute glomerulonephritis. Glomerulus is edematous and swollen, capillaries dilated and opened up, containing RBC acute inflammatory cells. Proliferation of mesangial cells and swelling of both parietal and visceral epithelial cells. Denudation of parietal epithelium cells from basement membrane also seen. Urinary space contains RBC's, albuminous fluid and WBC's. Tubular lumina show albumin and blood (H\&E, 40X)

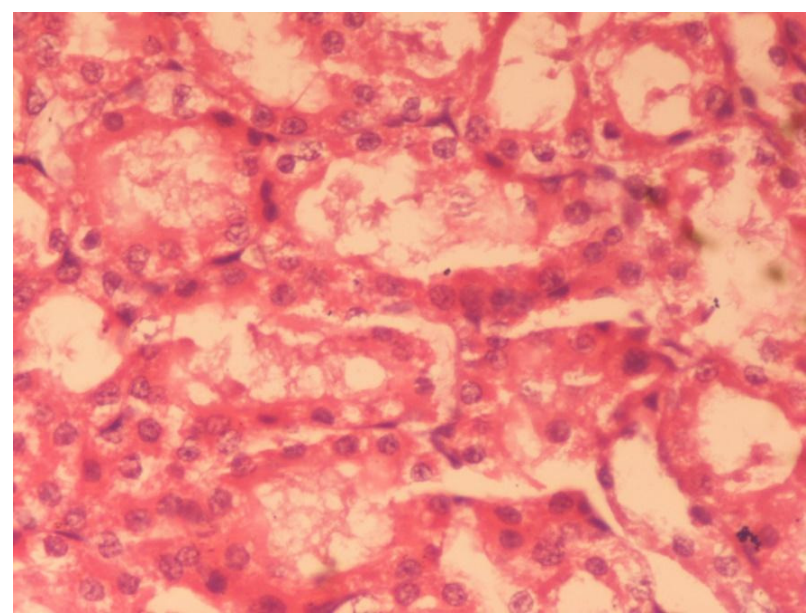

Fig. 4: Photomicrograph of experimental kidney: The PCT are lined by degenerating cuboidal cells showing highly eosinophilic cytoplasm and wisps of cytoplasm projecting in lumina. Lumen contains albumin, fibrin threads, RBC's and WBC's (H\&E, 40X)

\section{Histomorphometry}

Diameter of Bowman's capsule, glomerulus, proximal and distal convoluted tubules of control and experimental groups were compared and all the values were observed to be less in experimental group as compared to control group. The diameter of Bowman's capsule and glomerulus were also statistically significant (Table 1).

Table 1: Different measurements of kidney of control and experimental rats

\begin{tabular}{|c|c|c|c|}
\hline $\begin{array}{l}\text { Diameter } \\
(\mu \mathrm{m})\end{array}$ & $\begin{array}{l}\text { Control } \\
\text { (Mean } \pm \\
\text { SD) }\end{array}$ & $\begin{array}{c}\text { Experimental } \\
\text { (Mean } \pm \text { SD) }\end{array}$ & $\begin{array}{l}\text { Percent } \\
\text { change }\end{array}$ \\
\hline $\begin{array}{l}\text { Bowman's } \\
\text { capsule }\end{array}$ & $\begin{array}{c}127.14 \pm \\
16.29\end{array}$ & $\begin{array}{l}103.66 \pm \\
22.82^{* * \star \star} \pm\end{array}$ & $\square 18.47$ \\
\hline Glomerulus & $\begin{array}{r}95.95 \\
\pm 14.61\end{array}$ & $\begin{array}{l}82.29 \pm \\
22.297^{ \pm \star}\end{array}$ & $\square 14.24$ \\
\hline $\begin{array}{l}\text { Proximal } \\
\text { convoluted } \\
\text { tubules }\end{array}$ & $\begin{array}{l}42.41 \pm \\
7.13\end{array}$ & $\begin{array}{c}37.698 \pm \\
7.67^{\mathrm{NS}}\end{array}$ & $\square 11.11$ \\
\hline $\begin{array}{l}\text { Distal } \\
\text { convoluted } \\
\text { tubules }\end{array}$ & $\begin{array}{c}34.921 \pm \\
4.164\end{array}$ & $\begin{array}{l}31.349 \pm \\
3.583^{\mathrm{NS}}\end{array}$ & $\square 10.23$ \\
\hline
\end{tabular}

p value "*** $<0.001, * 0.01, "<0.02,{ }^{* s}$ Not significant

\section{DISCUSSION}

Degenerative changes are well marked in our experimental kidney in the form of glomerular edema and swollen capillary tufts, increased number of nuclei, haemorrhage and acute inflammatory cells and dilated capillaries. In a similar study Gulec et al, (2012) [4] reported focal necrosis in some areas of renal cortex and medulla after olanzapine intoxication in rats. The only difference between the aforesaid findings and our observations is that the former found degeneration in some areas only but ours is a generalized effect. It is interesting to note that in both the cases there is great affinity of the drug for parietal layer of Bowman's capsule.

Gulec et al. (2012) [4] found its basal lamina excessively thickened and we found excessive swelling of both parietal and visceral epithelial cells. Dilatation of arterioles and collection of large number of lymphocytes and histiocytes which infiltrate the interstitial tissue highlight excessive inflammatory process undergoing in the region of glomeruli. Such an extensive histopathological findings due to olanzapine treatment are lacking in literature. External pressure due to edema could compress the Bowman's capsule obliterating urinary space and decreasing the diameter of Bowmen's capsule as confirmed by histomorphometry. 
In kidney, D2 like receptors are found in glomeruli, renal tubules and post ganglionic sympathetic nerve terminals [13]. $\mathrm{H} 1$ histamine receptor is present in smooth muscles, endothelium and brain [14]. Presence of muscarinic receptors are well documented in nerves, heart, smooth muscles, glands and endothelium [15]. Location of serotonergic receptors are seen as 5-HT 2A in smooth muscles, platelet and cerebral cortex; $5-\mathrm{HT} 2 \mathrm{C}$ in choroid, hippocampus and substantia nigra; $5-\mathrm{HT}$ 1D in brain and 5-HT1A in raphe nucleus and hippocampus [14].

Aforesaid facts may be indicative of direct toxic effect of the drug on organs considered in our experiment. At the same time, the damaging effects of olanzapine on organs under consideration may also be an indirect expression due to its direct effects on other organs of the body.

Formation of reactive oxygen species is induced by the use of olanzapine [16] which may cause cellular damage and dysfunction [17]. It has been proved that using antioxidant can reduce the metabolic changes in rats receiving olanzapine [18]. Reactive oxygen species could also be generalized reason for changes in organs under consideration. Vascular factor may be another generalized reason for the degenerative changes in all our four organs of experimental rats. But this prediction needs further experimental studies for confirmation.

\section{REFERENCES}

1. Mitchell M, Riesenberg R, Bari MA, Marquez E, Kurtz D, Falk D, Hardy T, Taylor CC, Mitchell CP, Cavazzoni P. A doubleblind, randomized trial to evaluate the pharmacokinetics and tolerability of 30 or $40 \mathrm{mg} / \mathrm{d}$ oral olanzapine relative to $20 \mathrm{mg} / \mathrm{d}$ oral olanzapine in stable psychiatric subjects. Clin Ther. 2006; 28(6):881-892.

2. Bymaster FP, Calligaro DO, Falcone JF, Marsh RD, Moore NA, Tye NC, Seeman P, Wong DT. Radioreceptor binding profile of the atypical antipsychotic olanzapine. Neuropsychopharmacology. 1996; 14(2):87-96.

3. Richelson E, Souder T. Binding of antipsychotic drugs to human brain receptors focus on newer generation compounds. Life Sci. 2000; 68(1):29-39.
4. Gulec M, Ozcan H, Oral E et al. Nephrotoxic effects of chronically administered olanzapine and risperidone in male rats. Klin Psikofarmakol Bul Clin Psychopharmacol. 2012; 22(2):139-147.

5. Cohen R, Wilkins KM, Ostroff R, Tampi RR. Olanzapine and acute urinary retention in two geriatric patients. Am J Geriatr Pharmacother. 2007; 5(3):241-246.

6. Ahuja N, Palanichamy N, Mackin P, Lloyd A. Olanzapineinduced hyperglycaemic coma and neuroleptic malignant syndrome: case report and review of literature. $J$ Psychopharmacol. 2010; 24(1):125-130.

7. Meltzer H, Cola PA, Parsa M. Marked Elevations of Serum Creatine Kinase Activity Associated with Antipsychotic Drug Treatment. Neuropsychopharmacology. 1996; 15(4):395-405.

8. Filice GA, McDougall BC, Ercan-Fang N, Billington CJ. Neuroleptic malignant syndrome associated with olanzapine. Ann Pharmacother. 1998; 32(11):1158-1159.

9. Moltz DA, Coeytaux RR. Case report: possible neuroleptic malignant syndrome associated with olanzapine. J Clin Psychopharmacol. 1998; 18(6):485-486.

10. Burkhard PR, Vingerhoets FJ, Alberque $C$, Landis $T$. Olanzapine-induced neuroleptic malignant syndrome. Arch Gen Psychiatry. 1999; 56(1):101-102.

11. Sagar R, Varghese ST, Balhara YPS. Olanzapine-induced double incontinence. Indian J Med Sci. 2005; 59(4):163-164.

12. Vernon LT, Fuller MA, Hattab H, Varnes KM. Olanzapineinduced urinary incontinence: treatment with ephedrine. J Clin Psychiatry. 2000; 61(8):601-602.

13. Hussain T, Lokhandwala MF. Renal dopamine receptors and hypertension. Exp Biol Med (Maywood). 2003; 228(2):134-142.

14. Katzung BG. Histamine, serotonin and ergot alkaloids. In: Basic and Clinical Pharmacology. $13^{\text {th }}$ ed. Mc Graw Hill; 2015:437-468.

15. Katzung BG. Cholinoceptor-Blocking drugs. In: Basic and Clinical Pharmacology. $13^{\text {th }}$ ed. Mc Graw Hill; 2015:209-227.

16. Heiser P, Sommer O, Schmidt AJ Clement HW, Hoinkes A, Hopt UT, Schulz E, Krieg JC, Dobschütz E. Effects of antipsychotics and vitamin $C$ on the formation of reactive oxygen species. J Psychopharmacol. 2010; 24(10):1499-1504.

17. Halici Z, Keles ON, Unal D, Albayrak M, Suleyman H, Cadirci E, Unal B, Kaplan S. Chronically administered risperidone did not change the number of hepatocytes in rats: A stereological and histopathological study. Basic Clin Pharmacol Toxicol. 2008; 102(5):426-432.

18. Shertzer HG, Kendig EL, Nasrallah HA, Johansson E, Genter $M B$. Protection from olanzapine-induced metabolic toxicity in mice by acetaminophen and tetrahydroindenoindole. Int $\mathrm{J}$ Obes. 2010; 34(6):970-979. 